\title{
Efficacy of the pyrethroid compound possessing a new type of alcohol moiety
}

\author{
Masachika Hirano,* Isao OHno,* Shigeyoshi Kitamura,* \\ Toshio NishiokA* and Yoshio Fujita* \\ Research Department, Pesticide Division, Sumitomo Chemical Co., Ltd., \\ Takatsukasa, Takarazuka-shi, Hyogo 665 \\ (Received : February 2, 1978)
}

\begin{abstract}
A new type of pyrethroid compounds which possessed a linear type chemical structure in the alcoholic moiety was synthesized, and the lethal and knockdown activities of the compounds were studied. As the result, SP-3243 (1-ethynyl-2methyl-2-hexen-5-yn-1-yl 3-(2, 2-dichlorovinyl)-2, 2-dimethylcyclopropane-1-carboxylate) was found to possess the highest efficacy among these compounds against houseflies, mosquitoes and cockroaches.

The lethal activity of this compound against houseflies was more than 10 times higher than that of pyrethrins and allethrin. The knockdown activity of this compound against houseflies and mosquitoes was slightly inferior to that of pyrethrins, nevertheless, the efficacy of aerosol formulation was high enough. This compound also possessed insecticidal activity against cockroaches, but the efficacy was inferior to that of pyrethrins and permethrin.
\end{abstract}

Since the chemical structures of natural pyrethrins were elucidated by LaForge and Haller (1936), a number of studies on analoges of chrysanthemic acid esters have been conducted, and many insecticidal synthetic pyrethroids were discovered. These include allethrin (Schechter et al., 1949), tetramethrin (Kato et al., 1965), resmethrin (Elliot et al., 1967), furamethrin (Katsuda et al., 1969), proparthrin (Nakanishi et al., 1970), phenothrin (Fujimoto et al., 1973), butethrin (Sota et al., 1973b) and permethrin (Elliot et al., 1973). These pyrethroidal compounds possess the aromatics in the alcohol moieties.

On the other hand, Sota et al. (1973a) reported trans-2, 5-hexadien-1-yl chrysanthemate and related compounds as the pyrethroid compounds which possess no aromatics in the alcohol moieties. We synthesized, therefore, $\alpha$-ethynyl allyl alcohol derivatives to study the lethal and knockdown activities.

* 平野雅親, 大野 勲, 北村重義, 西岡敏雄, 藤田 義雄：住友化学工業(株) 農薬事業部研究部 (干665 兵庫県宝塚市高司 4 丁目 2 番 1 号)
As the result, it became clear that SP3243 (1-ethynyl-2-methyl-2-hexen-5-yn-1-yl 3(2, 2-dichlorovinyl)-2, 2-dimethylcyclopropane1-carboxylate) was found to possess the highest efficacy among these derivatives.

This paper describes the efficacies of SP3243 and the analoges against houseflies, mosquitoes, and cockroaches.

\section{Materials AND METHODS}

\section{Test insects}

The following stock colonies of houseflies, mosquitoes and cockroaches were reared in this laboratury at $27 \pm 1^{\circ} \mathrm{C}$ and at $60 \pm 5 \%$ in relative humidity.

(1) Houseflies Musca domestica. These susceptible strains of Lab-em-7-em, WHO and CSMA.

(2) Mosquitoes Culex pipiens pallens. Two susceptible strains of Sumitomo and Gose.

(3) German cockroach Blattella germanica. One susceptible strain of Sumitomo, 


\section{Chemicals}

The following synthetic chemicals were used in this study. SP-3243: The purity was higher than $95 \%$. The physical and chemical properties were presented in Table 1.

$\begin{array}{ll}\text { Allethrin : } & \text { Technical grade }(91.0 \%) \\ \text { S-bioallethrin : } & \text { Technical grade }(93.3 \%) \\ \text { Bioallethrin : } & \text { Technical grade }(90.9 \%) \\ \text { Tetramethrin : } & \text { Technical grade }(90.3 \%) \\ \text { Permethrin : } & \text { Technical grade }(92.9 \%) \\ \text { Cypermethrin : } & \text { Technical grade }(96.5 \%) \\ \text { Phenothrin : } & \text { Technical grade }(96.3 \%) \\ \text { Resmethrin : } & \text { Technical grade }(91.6 \%) \\ \text { Pyrethrins : } & \text { 20\% pyrethrum extract sup- } \\ & \text { plied by Dainippon Jochugi- } \\ & \text { ku Co., Ltd. }\end{array}$

\section{Testing methods}

(1) Topical application method (Okuno et al., 1976) with CSMA strain of houseflies.

(2) Campbell's turntable method (Campbell and Sullivan, 1938) with Lab-em-7-em strain of houseflies.

(3) Glass chamber method by oil or emulsifiable concentrate spray. After 10 female mosquitoes (oil with Sumitomo, EC with Gose) and 10 houseflies (WHO) were released in a glass chamber $\left(0.34 \mathrm{~m}^{3}\right), 0.6 \mathrm{ml}$ of each formulation was sprayed into the glass chamber through an atomizer at a pressure of $0.9 \mathrm{~kg} / \mathrm{cm}^{2}$. The number of knocked down insects was counted at various time intervals for $10 \mathrm{~min}$. $\mathrm{KT}_{50}$ value was calculated by Finney's graphic method. After $10 \mathrm{~min}$, the knocked down insects were collected and transferred into a recovery container to observe the mortality after $24 \mathrm{hrs}$.

(4) Mosquito coil test. After 10 female mosquitoes (Sumitomo) and 10 houseflies (WHO) were released in a glass chamber $\left(0.34 \mathrm{~m}^{3}\right), 1$ gram of test coil was fixed on a stand at the center of the chamber bottom and ignited at the both ends. The number of knocked down insects was counted at various time intervals for $24 \mathrm{~min}$ to calculate $\mathrm{KT}_{50}$ value. Mortality was recorded as same as (3).

(5) Film contact. One $\mathrm{ml}$ of acetone solution of each chemical was applied to $55 \mathrm{~cm}^{2}$ of an aluminium plate. After acetone was evaporated off, 10 adult cockroaches were released. After $24 \mathrm{hrs}$, the exposed cockroaches were transferred to a plastic cup, and the mortality was recorded at 48 hrs after treatment.

(6) Direct spray against cockroaches (Okuno et al., 1976).

(7) Aerosol test method against cockroaches. Test method was as in (6). Instead of oil formulation, each aerosol was used.

(8) Aerosol test method against the flying insects (Aerosol test method, 1965), the Gose strain of mosquitoes and the WHO strain of houseflies.

\section{Results AND Discussion}

1. Screening the pyrethroid compounds possessing the new alcohol moiety

Eight compounds shown in Table 1 were synthesized and the efficacies were examined. Among these compounds, those whose $R_{1}$ was alkynyl or alkenyl showed high lethal and knockdown activities against houseflies and mosquitoes.

Compound 5 ( $\mathrm{R}_{1}$ : allyl, $\mathrm{R}_{2}$ : methyl, $\mathrm{R}_{3}$ : hydrogen) was reported by Sota et al. (1973 a). However, the lethal activity of $\alpha$-ethynyl derivative of compound $5\left(\mathrm{R}_{1}\right.$ : allyl, $\mathrm{R}_{2}$ : methyl, $\mathrm{R}_{3}$ : ethynyl, namely compound 6 ) was 5 times higher than that of compound 5 , and the knockdown activity was also higher than that of compound 5 .

The lethal activity of compound $4\left(\mathrm{R}_{1}\right.$ : propargyl, $\mathrm{R}_{2}$ : methyl, $\mathrm{R}_{3}$ : ethynyl) was equal to that of compound 6 , nevertheless, the knockdown activity of compound 4 was much higher than that of compound 6 .

As the influence of $R_{2}$ on the efficacy was examined among the propargyl compounds, the efficacy of the methyl moiety was more effective than the hydrogen moiety. It showed the same tendency as the result reported by Sota et al. (1973a).

Moreover, compounds 7 and 8 were synthesized to compare with compounds 5 and 6 , but these were less effective than compounds 5 and 6 .

In conclusion, $\alpha$-ethynyl allyl alcohol esters possessed high lethal and knockdown activities against houseflies and mosquitoes. And, among these compounds, compound 4 (hereafter designated as SP-3243) showed the highest efficacy. 
Table 1 Chemical structures and efficacies of candidate compounds<smiles>[R1]C=C([R2])C([R3])OC(=O)C1(C)C(C=C(Cl)Cl)C1(C)C</smiles>

\begin{tabular}{|c|c|c|c|c|c|c|}
\hline \multirow{2}{*}{ Compound No. } & \multicolumn{3}{|c|}{ Chemical structures } & \multirow{2}{*}{$\begin{array}{c}\text { Turntable } \\
M . \text { domestica } \\
\mathrm{LC}_{50}(\mathrm{mg} / 100 \mathrm{ml})\end{array}$} & \multicolumn{2}{|c|}{ Oil $\underset{\mathrm{KT}_{50}(\mathrm{sec})}{(0.1 \%)}$} \\
\hline & $\mathrm{R}_{1}$ & $\mathrm{R}_{2}$ & $\mathrm{R}_{3}$ & & $C \cdot p .^{*}$ & M. d.** \\
\hline 1 & $\mathrm{HC} \equiv \mathrm{C}-\mathrm{CH}_{2}-$ & $\mathrm{H}-$ & $\mathrm{H}-$ & 500 & $>600$ & $>600$ \\
\hline 2 & $\mathrm{HC} \equiv \mathrm{C}-\mathrm{CH}_{2}-$ & $\mathrm{H}-$ & $\mathrm{HC} \equiv \mathrm{C}-$ & 72 & 204 & 252 \\
\hline 3 & $\mathrm{HC} \equiv \mathrm{C}-\mathrm{CH}_{2}-$ & $\mathrm{CH}_{3}-$ & $\mathrm{H}-$ & 96 & 255 & 312 \\
\hline $4 * * *$ & $\mathrm{HC} \equiv \mathrm{C}-\mathrm{CH}_{2}-$ & $\mathrm{CH}_{3}-$ & $\mathrm{HC} \equiv \mathrm{C}-$ & 25 & 232 & 275 \\
\hline 5 & $\mathrm{H}_{2} \mathrm{C}=\mathrm{C}-\mathrm{CH}_{2}-$ & $\mathrm{CH}_{3}-$ & $\mathrm{H}-$ & 120 & $>600$ & $>600$ \\
\hline 6 & $\mathrm{H}_{2} \mathrm{C}=\mathrm{C}-\mathrm{CH}_{2}-$ & $\mathrm{CH}_{3}-$ & $\mathrm{HC} \equiv \mathrm{C}-$ & 25 & 540 & 420 \\
\hline 7 & $\mathrm{HC} \equiv \mathrm{C}-\mathrm{CH}_{2} \mathrm{CH}_{2}-$ & $\mathrm{CH}_{3}-$ & $\mathrm{HC} \equiv \mathrm{C}-$ & 40 & 252 & 285 \\
\hline 8 & $\mathrm{H}_{2} \mathrm{C}=\mathrm{CHCH}_{2} \mathrm{CH}_{2}-$ & $\mathrm{CH}_{3}$ & $\mathrm{HC} \equiv \mathrm{C}-$ & 33 & $>600$ & $>600$ \\
\hline Phenothrin & & & & 40 & & \\
\hline Pyrethrins & & & & 320 & 180 & 178 \\
\hline
\end{tabular}

* Culex pipiens pallens

** Musca domestica

*** SP-3243

Table 2 Physical and chemical properties of SP-3243

\begin{tabular}{ll}
\hline \multicolumn{1}{c}{ Item } & Outlines of properties \\
\hline Empirical formula & $\mathrm{C}_{17} \mathrm{H}_{18} \mathrm{O}_{2} \mathrm{Cl}_{2}$ \\
Molecular weight & 325 \\
Appearance & Yellowish oily liquid \\
Refractive index & $n_{\mathrm{D}^{24.0} 1.5175}$ \\
Vapor pressure* & $2.0 \times 10^{-4} \mathrm{~mm} \mathrm{Hg}$ at $25^{\circ} \mathrm{C}$ \\
Solubility & Miscible with almost all \\
& of aromatic or aliphatic \\
& hydrocarbons and other \\
& organic solvents
\end{tabular}

* By gas-chromatographic determination

\section{Efficacy of SP-3243}

The physical and chemical properties of SP-3243 is shown in Table 2.

The lethal activity of SP-3243 against houseflies by topical application method was almost equal to that of permethrin and resmethrin and more than 10 times higher than that of pyrethrins and allethrin (Table 3). The lethal activity of SP-3243 against houseflies by Campbell's turntable method was superior to that of phenothrin and pyre-
Table 3 Insecticidal activity against Musca domestica by topical application method

\begin{tabular}{lll}
\hline \multicolumn{1}{c}{ Insecticide } & \multicolumn{2}{c}{ LD $50(\mu \mathrm{g} / \mathrm{fy})$} \\
\hline SP-3243 & 0.029 & $(0.025-0.034)^{*}$ \\
Permethrin & 0.022 & $(0.019-0.026)$ \\
Resmethrin & 0.034 & $(0.027-0.042)$ \\
Cypermethrin & 0.012 & $(0.007-0.026)$ \\
Allethrin & 0.53 & $(0.46-0.61)$ \\
Pyrethrins & 1.01 & $(0.89-1.14)$ \\
\hline
\end{tabular}

* Figures in parentheses indicate $95 \%$ confidence limit.

thrins as shown in Table 1.

SP-3243 possessed high knockdown activity against houseflies and mosquitoes also. Knockdown activity of the EC formulation was higher than that of tetramethrin and bioallethrin against houseflies, and was higher than that of tetramethrin but almost equal to that of bioallethrin against mosquitoes as shown in Table 5 . Knockdown activity of the oil formulation was almost equal to that of pyrethrins against mosquitoes, but less than that of pyrethrins and S-bioallethrin 
Table 4 Knockdown activity of oil formulations against Culex pipiens pallens and Musca domestica

\begin{tabular}{|c|c|c|c|c|c|c|c|}
\hline \multirow{2}{*}{ Insecticide } & \multirow{2}{*}{$\underset{(\%)}{\text { Conc. }}$} & \multicolumn{3}{|c|}{ C. pipiens } & \multicolumn{3}{|c|}{ M. domestica } \\
\hline & & & $T_{50}(\min )$ & Kill (\%) & & $T_{50}(\min )$ & Kill (\%) \\
\hline \multirow{2}{*}{ SP-3243 } & 0.05 & 7.2 & $(5.9-10.6)^{*}$ & 75 & 5.8 & $(5.0-6.6)$ & 60 \\
\hline & 0.1 & 3.9 & $(3.4-4.3)$ & 85 & 4.6 & $(3.7-5.8)$ & 80 \\
\hline Pyrethrins & 0.1 & 3.0 & $(2.4-3.7)$ & 90 & 3.0 & $(2.4-3.6)$ & 10 \\
\hline S-bioallethrin & 0.05 & 3.0 & $(2.5-3.5)$ & 100 & 3.0 & $(2.6-3.5)$ & 5 \\
\hline
\end{tabular}

* Figures in parentheses indicate $95 \%$ confidence limit.

Table 5 Efficacy of the emulsifiable concentrates and the oil-based aerosol formulations against Musca domestica and Culex pipiens pallens

\begin{tabular}{|c|c|c|c|c|c|c|c|c|c|}
\hline \multirow{3}{*}{ Insecticide } & \multirow{3}{*}{$\begin{array}{c}\text { Conc. } \\
(\%)\end{array}$} & \multicolumn{4}{|c|}{ Emulsifiable concentrate } & \multicolumn{4}{|c|}{ Oil-based aerosol } \\
\hline & & \multicolumn{2}{|c|}{ C. pipiens } & \multicolumn{2}{|c|}{ M. domestica } & \multicolumn{2}{|c|}{ C. pipiens } & \multicolumn{2}{|c|}{ M. domestica } \\
\hline & & $\underset{(\mathrm{min})}{\mathrm{KT}_{50}}$ & $\underset{(\%)}{\text { Kill }}$ & $\begin{array}{c}\mathrm{KT}_{50} \\
(\mathrm{~min})\end{array}$ & $\underset{(\%)}{\text { Kill }}$ & $\begin{array}{c}\mathrm{KT}_{50} \\
(\mathrm{~min})\end{array}$ & $\underset{(\%)}{\text { Kill }}$ & $\begin{array}{l}\mathrm{KT}_{50} \\
(\mathrm{~min})\end{array}$ & $\underset{(\%)}{\text { Kill }}$ \\
\hline \multirow{3}{*}{ SP-3243 } & 0.1 & 3.2 & 50 & 5.2 & 45 & 6.6 & 30 & 15.3 & 31 \\
\hline & 0.2 & 3.2 & 100 & 2.7 & 85 & 3.7 & 91 & 9.5 & 64 \\
\hline & 0.4 & & & & & 2.5 & 86 & 6.1 & 70 \\
\hline \multirow{2}{*}{ Tetramethrin } & 0.1 & $>10$ & 20 & 9.2 & 0 & & & & \\
\hline & 0.2 & $>10$ & 25 & 4.2 & 30 & & & & \\
\hline Bioallethrin & 0.1 & 3.7 & 11 & 9.6 & 15 & & & & \\
\hline \multirow{2}{*}{ Pyrethrins } & 0.15 & & & & & 12.0 & 70 & $>20$ & 一 \\
\hline & 0.3 & & & & & 7.0 & 86 & $>20$ & 11 \\
\hline OTA* & & & & & & 14.2 & 100 & 10.9 & 66 \\
\hline
\end{tabular}

* OAT means official test aerosol, and contains $0.2 \%$ of pyrethrins and $1.6 \%$ of piperonyl butoxide.

Table 6 Efficacy of the mosquito coil formulations against Culex pipiens pallens and Musca domestica

\begin{tabular}{|c|c|c|c|c|c|}
\hline \multirow{2}{*}{ Insecticide } & \multirow{2}{*}{$\begin{array}{c}\text { Conc. } \\
(\%)\end{array}$} & \multicolumn{2}{|c|}{ C. pipiens } & \multicolumn{2}{|c|}{ M. domestica } \\
\hline & & $\mathrm{KT}_{50}(\mathrm{~min})$ & $\mathrm{Kill}(\%)$ & $\mathrm{KT}_{50}(\mathrm{~min})$ & Kill (\%) \\
\hline \multirow{2}{*}{ SP-3243 } & 0.3 & 8.5 & 60 & 17.0 & 0 \\
\hline & 0.6 & 7.2 & 65 & 11.5 & 10 \\
\hline \multirow{2}{*}{ Allethrin } & 0.3 & 4.4 & 15 & 13.0 & 0 \\
\hline & 0.6 & 4.3 & 82 & 10.5 & 10 \\
\hline
\end{tabular}

against houseflies as shown in Table 4 .

The efficacy of SP-3243 in mosquito coil agent was less than that of allethrin (Table 6).

The oil-based aerosol formulation of SP. 3243 was more effective than that of pyrethrins and official test aerosol against mosquitoes, and than that of pyrethrins against houseflies as shown in Table 5. The efficacy of $0.2 \%$ aerosol formulation of SP-3243 against houseflies was almost equal to that of official test aerosol. SP-3243 showed not only high knockdown activity but also high lethal activity in case of the oil-based aerosol formulation.

The lethal activfty oi SP-3243 against cockroaches was less than that of permethrin, resmethrin and pyrethrins by each test method as shown in Table 7. And, the knockdown acti- 
Table 7 Insecticidal activities against Blattella germanica

\begin{tabular}{lcc}
\hline \hline Insecticide & $\begin{array}{c}\text { Film contact } \\
\text { LD }\end{array}$ (mg/m $\left.\mathrm{m}^{2}\right)$ & $\begin{array}{c}\text { Topical application } \\
\text { LD }\end{array}$ \\
\hline SP-3243 & 5.2 & 0.70 \\
Permethrin & 2.0 & 0.34 \\
Resmethrin & 4.0 & - \\
Pyrethrins & 2.5 & 0.62 \\
\hline
\end{tabular}

Table 8 Knockdown activity of oil formulation against Blattella germanica

\begin{tabular}{lllc}
\hline Insecticide & $\begin{array}{c}\text { Conc. } \\
(\%)\end{array}$ & $\mathrm{KT}_{50}(\mathrm{~min})$ & $\begin{array}{c}\text { Mortality } \\
(\%)\end{array}$ \\
\hline \multirow{2}{*}{ SP-3243 } & 0.025 & $>20$ & 70 \\
& 0.05 & $6.2(4.5-8.8) *$ & 100 \\
Pyrethrins & 0.025 & $2.6(1.8-3.5)$ & 100 \\
& 0.05 & $2.4(1.9-3.1)$ & 90 \\
\hline
\end{tabular}

* $95 \%$ confidence limit

Table 9 Efficacy of the oil-based aerosol formulations against Blattella germanica

\begin{tabular}{|c|c|c|c|c|c|c|c|}
\hline \multirow{2}{*}{ Composition } & \multirow{2}{*}{$\begin{array}{c}\text { Dosage } \\
\left(\mathrm{mg} / 2,900 \mathrm{~cm}^{3}\right)\end{array}$} & \multicolumn{5}{|c|}{$\%$ Knockdown at elapsed time $(\min )$} & \multirow{2}{*}{$\begin{array}{l}\text { Kill (\%) } \\
\text { in } 72 \mathrm{hrs}\end{array}$} \\
\hline & & 1.3 & 2.5 & 5.0 & 10.0 & 20.0 & \\
\hline \multirow{2}{*}{ SP-3243 } & 90 & 20 & 20 & 40 & 30 & 60 & 10 \\
\hline & 70 & 10 & 30 & 40 & 70 & 90 & 0 \\
\hline \multirow{2}{*}{ Pyrethrins \{} & 85 & 25 & 50 & 55 & 60 & 60 & 5 \\
\hline & 100 & 25 & 40 & 40 & 65 & 80 & 30 \\
\hline \multicolumn{2}{|l|}{ Untreated } & 0 & 0 & 0 & 0 & 0 & 0 \\
\hline
\end{tabular}

vity of this compound against cockroaches was inferior to that of pyrethrins as shown in Table 8. Besides, the efficacy of oil-based aerosol formulation of this compound was slightly less than that of pyrethrins (Table 9).

In conclusion, SP-3243 possessed not only high lethal activity but also knockdown activity against houseflies and mosquitoes. Especially, the oil-based aerosol formulation of this compound was excellent. Nevertheless, the efficacy against cockroaches was slightly lower than that of pyrethrins, permethrin and resmethrin.

\section{REFERENCES}

Aerosol test method (1915): Aerosol and pressurized space spray insecticide test method for flying insects. Soap and Chemical Specialities Blue Book, pp. 236-238.

Campbell, F. L. and W. N. Sullivan (1938): Testing fly sprays, a metal turntable method for comparative tests of liquid spray contact insecticides. Soap Sanit. Chem. 14(6) : 119149.

Elliot, M., A. W. Farnham, N. F. Janes, P. H. Needham and B. C. Pearson (1967): 5-Benzyl3-furylmethyl chrysanthemate, a new potent insecticide. Nature, 213 : 493-494.

Elliot, M., A. W. Farnham, N. F. Janes, P. H.
Needham, D. A. Pulman and J. H. Stevenson (1973): A photostable pyrethroid. Nature, 246 : 169-170.

Fujimoto, K., N. Itaya, Y. Okuno, T. Kadota and T. Yamaguchi (1973): A new insecticidal pyrethroid ester. Agric. Biol. Chem., 37(11): 2681-2682.

Kato, T., K. Ueda and K. Fujimoto (1965): New insecticidally active chrysanthemates. Agric. Biol. Chem., 28(12) : 914-915.

Katsuda, Y., T. Chikamoto, H. Ogami, H. Hirobe and T. Kunishige (1969): Novel insecticidal chrysanthemic esters. Agric. Biol. Chem., 33(9): 1361-1362.

LaForge, F. B. and H. L. Haller (1936): Constituents of pyrethrum flowers VI. The structure of pyrethrolone. J. Am. Chem. Soc., 58 : 1777-1780.

Nakanishi, M., A. Tsuda, K. Abe, S. Inamasu and T. Mukai (1970): Insecticidal activity of a new pyrethroid kikuthrin, studies on insecticide III. Botyu-Kagaku, 35(3): 91-96.

Okuno, Y., T. Yamaguchi and Y. Fujita (1976): Insecticidal activity of a new synthetic pyrethroidal compound, 3-phenoxy benzyl- $(+) c i s$, trans chrysanthemate ( $d$-phenothrin). BotyuKagaku, 41(1) : 42-55.

Schechter, M. S., N. Green and F. B. LaForge (1949): Constituents of pyrethrum flowers. XXIII. Cinerolone and the synthesis of related cyclopentenolones. J. Am. Chem. Soc., 71: 
3165-3173.

Sota, K., T. Amano, A. Hayashi and I. Tanaka (1973a): Trans-2, 5-hexadien-1-yl chrysanthemates and related esters. Agric. Biol. Chem., 37 : 1019-1025.

Sota, K., T. Amano, A. Hayashi and I. Tanaka (1973b) : New insecticidal cyclopropanecarboxylic esters. Part IV. 4-Aryl-2-buten-1-yl chrysanthemates and related esters. Botyu-Kagaku, 38(4) : 181-190.

\section{摘 要}

新しいアルコールを有するピレスロイド 化合物の殺虫効果

アルコール側に環状基を含まない新しいタイプのピレ スロイド化合物を多数合成し，イエバエ，アカイエカお よびチャバネゴキブリに対する致死效果とノックダウン 効果について検討した.

その結果, SP-3243（1-エチニル-2-メチル-2-へキセン -5-イン-1-イル 3-(2, 2-ジクロロビニル)-2, 2-ジメチルシ クロプロパン-1ーカルボキシレート)がもっとも高い活性 を示した．SP-3243のイエバエに対する致死効果は，ピ レトリンやアレスリンの約10倍であり，ノックダウン効 果も認められた. とくにエアン゙ールの効果が優れてい た. 一方，チャバネゴキブリに対する効果はピレトリン やレスメスリンには及ばなかった。

\section{新著紹介}

\section{Venoms : Chemistry and Molecular Biology}

T. Tu. Anthony（コロラド州立大学生化学教室）

Wiley, New York, 1977, 560 pp.

動物毒はなにかしら魅力がある. 動物毒作用の生物学 的活性は多様で, 複雑で, 興味深く,また, それに含ま れる物質から未知の有益な物質が発見される可能性があ る.

このたび動物毒の莫大な資料をもとに，著者の研究成 果を含めた Venoms が出版されたことは，医動物をは ごめ生化学, 薬理学, 生理学, 生物学の領域にたずさわ る者の大きな喜びである. 従来の動物毒関係の出版物と ちがって, 動物毒の化学, 分子生物学の立場から論じら れている点が大きな特徴である.
この本の大部分は，著者の専門であるへビ毒にさかれ ているが，クモ，サソリ，八チ，アリなどの節足動物毒 や短いながらトカゲ毒も含まれている．4章からなり第 1 章から第 3 章で, ヘビ毒の非タンパク成分, 酵素, タ ンパク成分の特性と作用が論じられている. とくに第 3 章には毒へビの大系や薬理作用，病理所見，純毒の構成 成分が含まれ，世界の毒へビおよびへビ毒の大要が要約 されている. ヘビ毒の生物活性として示されている神経 毒, 心臟毒, 細胞毒, 出血毒, 溶血毒などの活性は, そ の他の動物毒の活性を代表するものであり，その作用機 序も詳細に論んじられていてわかりやすい，第 4 章に節 足動物毒とトカゲ毒が含まれている，短いながら従来の 研究成果と今後の研究課題が示唆されている.

多くの研究成果を正しく評価し，わかりやすい項目に 整理し，重要な文献をほとんどもれなく含んだ大著はめ ずらしく，多くの研究者の参考になる本である.

(大利昌久) 